\title{
Communication
}

[Comunicação]

\section{Evaluation of tracheal wash of horses with exercise-induced pulmonary hemorrhage treated with furosemide}

\author{
[Avaliação do lavado traqueal de eqüinos portadores de hemorragia pulmonar induzida pelo \\ exercício tratados com furosemida] \\ R.M. Hegedüs ${ }^{1}$, L.E.S. Michima ${ }^{2}$, V.R.C. Souza ${ }^{3}$, G.H.P. Dutra ${ }^{4}$ \\ W.R. Fernandes ${ }^{5}$ C.S. Coelho ${ }^{4 *}$ \\ ${ }^{1}$ Aluna de graduação - UNIMONTE - Santos, SP \\ ${ }^{2}$ Aluna de pós-graduação - FMVZ-USP - São Paulo, SP \\ ${ }^{3}$ Aluno de pós-graduação - ICB-USP - São Paulo, SP \\ ${ }^{4}$ UNIMONTE - Santos, SP \\ ${ }^{5}$ Faculdade Medicina Veterinária e Zootecnia - USP - Santos, SP
}

\begin{abstract}
Exercise-induced pulmonary hemorrhage (EIPH), which is characterized by pulmonary hypertension, intra-alveolar hemorrhage and presence of blood in the airways, is one of the major causes of reduced athletic performance in horses. It occurs primarily in Thoroughbred and Standardbred racehorses bred in the United States and Canada (Birks et al., 2003).
\end{abstract}

The cytology of tracheal wash (TW) or bronchoalveolar lavage (BAL) of those animals may reveal erythrophagocytosis, erythrocytes and hemosiderophages, which are macrophages containing degradation products of hemoglobin. Hemosiderophages are commonly found in racehorses and in those used for extenuated exercises and indicate pulmonary hemorrhage or previous presence of blood in the airways. The presence of hemosiderophages in the TW has been used for detection of EIPH (Erickson et al., 2000), but it could not be established when bleeding happened (Erickson and Poole, 2002).

Ithen most athletic horses, furosemide is the principal drug given for prevention of EIPH (Birks et al., 2003). It increases urine production, reduces blood and plasma volumes and body weight. This was suggested to cause hemodynamic effects like reductions in right atrial and pulmonary arterial pressures and significant increases of systemic vascular resistance and cardiac output (Erickson et al., 2000; Kindig et al., 2001). Furthermore, furosemide has bronchodilatory properties that have been demonstrated to reduce airway resistance in ponies and horses (Kindig et al., 2001).

The aim of this study was to determine the effects of furosemide on the incidence and severity of EIPH by the comparison of tracheal washes obtained after intense exercise of racehorses diagnosed with the disease in the Jockey Club of Sao Vicente - São Paulo State Brazil.

Nine Thoroughbred horses were used in this study. They were kept under similar feeding and management conditions. The sample population consisted of three animals in each group. The control group was composed by healthy animals (EIPH-free established by physical and endoscopic evaluations); group 1 was composed

Recebido em 28 de março de 2006

Aceito em 12 de fevereiro de 2007

*Mailing address (endereço para correspondência)

Rua General Góis Monteiro, 665/51B

05029-000 - São Paulo, SP

*E-mail: clarissecoelho@yahoo.com.br 
of animals diagnosed with EIPH but not treated with furosemide before exercise; and group 2 was composed by animals diagnosed with EIPH and treated with $1 \mathrm{mg} / \mathrm{kg}$ of furosemide ${ }^{1}, \mathrm{IV}, 4$ hours before intense exercise.

All the horses were trained on the high-speed sand racetrack of the Sao Vicente Jockey Club $(1,600 \mathrm{~m})$. After a low-intensity warm-up by walk over a 5-minute period $(3 \mathrm{~m} / \mathrm{s})$, they completed two laps at $9 \mathrm{~m} / \mathrm{s}$. This was followed by a cool-down period longer than 5 minutes.

All the equines of the three experimental groups presented good performance during the exercise finishing it without muscular distress, lameness or uncommon alteration of clinical parameters.

Tracheal wash was collected two hours postexercise according to a previously described method (Mansmann and Knight, 1972). The fluid was immediately aspirated into a sterile flask for cytologic examination at the Centro Universitário Monte Serrat. Twenty milliliters of the sample was centrifuged for 8 minutes and direct smears were made and stained with MayGrunwald-Giemsa and Panotic stain four hours after the end of the trial to minimize the variability in staining. Differential cell count was obtained by counting 300 cells/slide from direct smears and then the mean values were calculated.

For red blood cell (RBC) count, samples were resuspended in isotonic solution ${ }^{2}$ and $2 \mathrm{ml}$ of Nattherrick solution was added to 20 microliters of the suspension. RBC was counted on Neubauer chamber (hemocytometer) in optic microscope $(400 \mathrm{x})$ and data are presented as RBC per milliliter of recovered tracheal wash fluid. Macroscopic evaluation of the tracheal wash samples was made soon after collection and four of them were blood-tinged.

In the present study, an increase of neutrophils was observed in the tracheal wash of EIPH group ( $16.9 \%$ for group 1 and $21.1 \%$ for group 2$)$ when compared to values of the control group (9.7\%). Associated with the increase on neutrophils, there was an elevation on eosinophils in the tracheal washes of groups 1 and 2 (EIPH-

\footnotetext{
${ }^{1}$ Zalix ${ }^{\circledR}$ - Intervet do Brasil - São Paulo, Brasil

${ }^{2}$ Isocellm ${ }^{\circledR}$ - Quimiolab - Chapecó, Brasil
}

diagnosed), respectively $4.5 \%$ and $15.8 \%$, which were higher than the control group $(2.7 \%)$. Neutrophils and eosinophils are inflammatory cells that migrate to sites of bleeding causing further damage via their mediators (Doucet and Viel, 2002a). The same authors related that EIPH can lead to neutrophilic inflammation and the high values in the EIPH group of the present study suggest that inflammation was really present. In a study that compared tracheal washes and BAL in racehorses (Hughes et al., 2003), eosinophils were predominantly found in samples of upper airways and their presence can indicate concomitant allergic pulmonary disease. No relevant alterations were observed for lymphocytes and epithelial cells.

The most important result of this study was the reduction in hemosiderophages in horses treated with furosemide prior to the exercise. When comparing the values obtained in group $1(7.8 \%)$ and control group $(0.3 \%)$ EIPH promoted an increase of hemosiderophages because the bleeding episode leaded to the necessity of phagocytosis activity over the RBC inside the alveolar space. Beside the elevation of hemosiderophages proportion, there was an associated reduction of macrophages (from $60.3 \%$ in control group to $55.7 \%$ in group 1 ), which were transformed in new hemosiderophages when they the phagocytosis over RBC. Furosemide did not eliminate EIPH, but it decreased bleeding signals, which was initially characterized by reduction of hemosiderophages (from $7.8 \%$ in group 1 to $4.2 \%$ in group 2) and a higher reduction on macrophages (from $55.7 \%$ in group 1 to $38.6 \%$ in group).

Most of the studies in the literature as research source used BAL to diagnose EIPH. However, some authors (Erickson et al., 2000; Birks et al., 2003) related that tracheal wash can also be used to detect EIPH by determining the presence of hemosiderophages in the aspirated fluid. In order to occur the formation of these cells, RBC must be degraded to hemoglobin and ferritin before hemosiderin is formed and then this implies in a certain delay between the bleeding episode and the detection of hemosiderin (Doucet and Viel, 2002b). Furthermore, the longevity of hemosiderophage in horses is currently unknown. Some authors related that they remain present in both BAL and tracheal wash fluids for 
up to 3 weeks after a single EIPH episode (Birks et al., 2003). So, if not made on the right moment, hemosiderophages may not be identified which would make difficult the diagnose. Migration of secretions from lower to upper airways occurs because physical exercise increases pulmonary movement and the expirated airflow (Malikides et al., 2003). Based on this observations, it was possible to identify the cell population and to make characterization of hemosiderophages, principally in groups 1 and 2. Results for each cell type were expressed as relative values (\%) as also related by authors in the literature (Malikides et al., 2003).

Beside hemosiderophages reduction, other important result that indicates a reduction of bleeding severity was a decrease in the RBC in tracheal washes of equines treated with furosemide (group 2). Malikides et al (2003) related a significantly reduction of $\mathrm{RBC}$ in the $\mathrm{BAL}$ of horses that received furosemide
$(0.5 \mathrm{mg} / \mathrm{kg}, \mathrm{IV}) 4$ hours before exercise, and their experiment was performed in a treadmill. In a similar study that evaluated the efficacy of nasal strip and furosemide in EIPH, Erickson and Poole (2002) showed that the administration of the diuretic are mentioned decreased it from $55.0 \pm 35.2 \times 10^{6}$ cells $/ \mathrm{ml}$ to $5.2 \pm 3.0 \times 10^{6}$ cells $/ \mathrm{ml}$, similarly the values found in the present study, in which there was a reduction from $77.6 \times 10^{6}$ $\mathrm{RBC} / \mathrm{ml}$ to $8.0 \times 10^{6} \mathrm{RBC} / \mathrm{ml}$ (with control group showing $1.0 \times 10^{6} \mathrm{RBC} / \mathrm{ml}$ ).

In a preliminar conclusion, furosemide minimizes the signals of EIPH, which was proved by the reduction in hemosiderophages number and RBC count in the tracheal washes of EIPH-diagnosed horses treated with the drug when compared with animals also diagnosed and not treated.

Keywords: equine, pulmonary hemorrhage, tracheal wash, furosemide

\section{RESUMO}

Avaliaram-se os efeitos da furosemida sobre o lavado traqueal de eqüinos portadores de hemorragia pulmonar induzida pelo exercício (HPIE). Nove animais foram distribuídos em três grupos experimentais: grupo-controle, formado por três eqüinos hígidos e não portadores da doença; grupo 1, com três eqüinos portadores e não submetidos a tratamento; e grupo 2, com três eqüinos portadores da doença e tratados com furosemida na dose de $1 \mathrm{mg} / \mathrm{kg}$, quatro horas antes da atividade atlética. As amostras do lavado traqueal foram obtidas duas horas após o exercício físico e sua avaliação demonstrou que o uso do medicamento reduziu a severidade da HPIE, refletida pela redução no número relativo de hemossiderófagos (de 7,8\% no grupo 1 para 4,2\% no grupo 2) e no número de eritrócitos (de $77666 \times 10^{3} / \mathrm{ml}$ no grupo 1 para $8000 \times 10^{3} / \mathrm{ml}$ no grupo 2).

Palavras-chave: eqüino, hemorragia pulmonal, lavado traqueal, furosemida

\section{REFERENCES}

BIRKS, E.K.; DURANDO, M.M.; McBRIDE, S. Exerciseinduced pulmonary hemorrhage. Vet. Clin. N. Am.: Equine Pract., v.19, p.87-100, 2003.

DOUCET, M.Y.; VIEL, L. Clinical, radiographic, endoscopic, bronchoalveolar lavage and lung biopsy findings in horses with exercise-induced pulmonary hemorrhage. Can. Vet. J., v.43, p.195-202, 2002a.

DOUCET, M.Y.; VIEL, L. Alveolar macrophage graded hemosiderin score from bronchoalveolar lavage in horses with exercise-induced pulmonary hemorrhage and controls. $J$. Vet. Inter. Med., v.16, p.281-286, 2002 b.

ERICKSON, H.H.; POOLE, D.C. Exercise-induced pulmonary hemorrhage. In: LEKEUX P. Equine Respiratory Diseases. Ithaca (NY): International Veterinary Information Service 2002: Disponível em :http://www.ivis.org/special_books/Lekeux/erickson/chapter_ frm.asp?LA=1. Acessado em: 06 ago 2005.
ERICKSON, H.H.; KINDIG, C.A.; POOLE, D.C. Exerciseinduced pulmonary hemorrhage: a new concept for prevention. J. Equine Vet. Sci., v.20, p.164-167, 2000.

HUGHES, K.J.; MALIKIDES, N.; HODGSON, D.R. et al. Comparison of tracheal aspirates and bronchoalveolar lavage in racehorses. 1. Evaluation of cytological stains and the percentage of mast cells and eosinophils. Aust. Vet. J., v.81, p.681-684, 2003.

KINDIG, C.A.; MCDONOUGH, P.; FENTON, G. et al. Efficacy of nasal strip and furosemide in mitigating EIPH in Thoroughbred horses. J. Appl. Physiol., v.91, p.1396-1400, 2001.

MANSMANN, R.A.; KNIGHT, H.D. Tracheal aspiration in the horse. J. Am. Vet. Med. Assoc., v.160, p.1527-1529, 1972.

MALIKIDES, N.; HUGHES, K.J.; HODGSON, D.R. et al. Comparison of tracheal aspirates and bronchoalveolar lavage in racehorses. 2. Evaluation of the diagnostic significance of neutrophil percentage. Aust. Vet. J., v.81, p.685-687, 2003. 